\title{
Transformations in Community Associations and Political Processes in a Rio de Janeiro "Favela"
}

Livia De Tommasi

Universidade Federal do ABC, Programa de Pós-Graduação em Ciências Humanas e Sociais, São Bernardo do Campo/SP, Brasil

Dafne Jazmin Velazco

Universidade do Estado do Rio de Janeiro, Programa de Pós-graduação em Ciências Sociais, Rio de Janeiro/RJ, Brasil

\begin{abstract}
The result of field research conducted in a Rio de Janeiro favela, the article discusses transformations in the organization of community associations. In particular, it describes the weakening of local associations that are traditionally regarded as representative of the community and the rise of new forms of association, indicating their distinctive characteristics in terms of relations with external agents (from the state and other spheres) and forms of organization and action. We place these processes in a long timeframe, prior to the installation of the Police Pacification Units in 2009 and to the following entrance of new state and private agents. We review critical events in the history of the local political organization, to discuss the multiple assemblages that affect the organization of the favela residents.
\end{abstract}

Key words: favela, political process, community organizations, entrepreneurship, government of the poor. 


\section{Transformações no associativismo local e processos políticos numa "favela" carioca}

\section{Resumo}

Fruto de uma pesquisa de caráter etnográfico numa favela da cidade do Rio de Janeiro, o artigo discute as transformações ocorridas nos processos de organização dos moradores. Em particular, descreve o enfraquecimento das associações locais que tradicionalmente se consideravam como "porta-vozes" da "comunidade" e o surgimento de novas formas de associativismo, apontando suas características distintivas com respeito às relações estabelecidas com agentes externos (estatais e não) e às formas de organização e atuação. Procuramos situar esse processo num tempo longo, anterior à instalação da Unidade de Policia Pacificadora em 2009, e à sucessiva entrada de novos agentes estatais e privados. Repercorrendo alguns acontecimentos críticos na história da organização política local, queremos discutir os múltiplos agenciamentos que afetam o processo de organização dos moradores nas favelas.

Palavras chaves: favela, associativismo, organizações comunitárias, empreendedorismo, governo dos pobres 


\title{
Transformations in Community Associations and Political Processes in a Rio de Janeiro "Favela"
}

\author{
Livia De Tommasi \\ Dafne Jazmin Velazco
}

\section{Introduction}

In late 2010 we began to frequent ${ }^{1}$ the Cidade de Deus, a neighborhood in the Zona Oeste, the western region of the city of Rio de Janeiro, to observe the transformations in the relations between state agents and local associations after the installation of the Unidade de Polícia Pacificadora (UPP) [Police Pacification Unit]. ${ }^{2}$ An informal conversation with one of the administrators of the Social Police Pacification Unit program $^{3}$ sparked our attention and motivated our choice of that region as a field of research. She said that in the Cidade de Deus, the program had found a particularly fertile ground for conducting a "strong listening" to the demands of the "community"4 and a diagnosis of their needs, supposedly the main objectives of the program, because of the presence of a Community Committee that brought together and gave political strength to the local organizations. The Committee had even developed a Local Development Plan (2004) to systematize its demands, diagnoses and planning for actions.

We soon perceived that describing and understanding the tangle of relations among the local agents (mostly members of non-governmental organizations (NGOs), which had been created by residents or former residents and with offices and most of their activity at the location) and of these with state agents, was not an easy task. To the contrary, it was extremely delicate to speak of something that strongly stirred the tempers, conflicts and reputation of our interlocutors. We also realized that the dynamics of local associations were quite different from the epic narratives ${ }^{5}$ that our interlocutors used to tell their stories of struggle. We particularly noticed the distance of the group of so-called "leaders" from residents, which was manifest in the scarce presence of residents at any activity promoted by the leaders. Speaking with residents (shop owners and sales people, participants in a social project, young students) we perceived that they are usually unaware of the existence of the Community Center and do not know its leaders. To the contrary, the later were known and legitimated in their role as representatives of the "community" by

1 Our study, of an ethnographic nature, has resulted in a few published articles (Tommasi \& Velazco 2013 and 2016, Tommasi 2014b), as well as a final course project for a bachelor's degree in the social sciences of Dafne Velazco (2013) and her master's dissertation (Velazco 2017).

2 In 2009 the Rio de Janeiro state government began, with much fanfare, a program that sought to break from the pattern of "fighting crime" that until then in the city had mostly involved fast and violent incursions by the police into favelas to supposedly repress drug trafficking. With the installation of the Police Pacification Units (UPPs) the military and police forces began to occupy favelas in a more stable manner, supposedly acting according to principles of what is known as "proximity policing". By 201637 UPPs had been installed in the favelas in the city. About this controversial process see, among others, Cano (2012), Malaguti (2011).

3 UPP Social is a program launched in 2010 by the Rio de Janeiro state government to act in the so-called "pacified areas" to articulate local demands with the interventions of various state and private agencies.

4 We use quotation marks for terms used in the native sense. In Brazil "community" is the "politically correct" term in contrast to the term "favela" (historically considered negative) to designate the territories at the margins of cities. Introduced by the Catholic Church in the 1950s (cf. Valladares 2005) the term "community" presupposes a "communion" among residents, which is valued in the realm of projects aimed at "community development". Currently, the more politicized residents prefer to use the term "favela" as a positive demand for identity (associated to struggle).

5 "A myth is not necessarily a false or invented story; it is a story that becomes significant to the degree to which it expands the meaning of an individual event (whether factual or not) transforming it in the, symbolic and narrative formalization of the self representations shared by a culture" (Portelli 1998: 118). 
outside agents (members of local governments, coordinators of NGOs in the city, academics, politicians, managers of third sector entities). Nevertheless, when the local agents spoke about the difficulties found in strengthening the "community organization" and its political struggle, they frequently blamed this on the interference of these outside agents. "They did everything to divide us", said one of the local leaders who was best known (from the outside). This statement resonated with us during the years of our field research, and became something that needed to be better understood. The tone of the criticism referred to the dichotomy, which is regularly repeated and revised in the moments of interaction (meetings, forums, public events), between those who are "born and raised" in the Cidade de Deus and outside agents; a dichotomy frequently used to legitimate statements (and speakers).

Other processes also called our attention, specifically the entrance of programs, projects and public and private agents dedicated to stimulating what we call "community based entrepreneurship" (Tommasi and Velazco 2013). These events appear to us to reveal something quite significant about the transformations underway: the supposed integration of the needy populations to the city was being realized through incentives to the market, to consumption, access to credit and not through the recognition and enactment of rights that guarantee the "appropriation of the city" (Machado da Silva 2002).

Thus, despite having participated actively in many meetings and events organized by the Committee, and having spoken with a number of its members, and even having been exclude this portion of our observations and reflections from the research material that we worked with to prepare some earlier texts (Tommasi \& Velazco 2013; Tommasi, 2014b). We, researchers from the outside, decided at that time to not present the difficulties, conflicts, ambiguities and impasses that appeared to us to characterize relations among the local political actors.

We continued, however, to accompany activities and events that involved the members of the local organizations. Over these years, we observed the birth of new organizations, new forms of association, new actors becoming mobilized, new ranges of relations resulting from the action of public and private agents and projects. In fact, the installation of the Police Pacification Unit caused the entrance at the location of a significant number of economic political and social interventions. Today, as in the past - and even more - (cf. Cunha 2016), the territories at the margins of the city are territories in dispute, produced by multiple agencyings. We also observed accusatory categories being used to break alliances and mark divisions, between the "born and raised" and those from the outside and between different generations of militants; we observed symbolic frontiers shifting, between residents living in different regions of the Cidade de Deus.

Finally, in 2014 we observed the construction of a new housing complex at a site that had been abandoned to garbage and where pigs wandered loose, which sat along a highly polluted stream that ran through the Cidade de Deus. This was the arrival of the federal low income housing program called Minha Casa Minha Vida [My Home My Life] (cf. Cardoso 2013). The apartments were initially allocated to residents who, after more than 30 years, were still living in the tiny and precarious "triage" houses in which they had been placed during the first large occupation of the Cidade de Deus after the destruction or removal of other "favelas" in the city, in the mid 196os. During one meeting, a young resident of a triage house, who should have been selected to move to the new housing project, called attention to the lack of transparency in the administration of the project and the arbitrary assignment of the new housing (to which residents of other regions of the city were being transferred). In a rapid questioning, we discovered the involvement of ambiguous people linked to influential politicians from the Cidade de Deus (and also, they told us, to drug trafficking), responsible for the realization of the registrations (the list of the future residents of the project). We then questioned the leaders of the local associations, to understand why the delicate process of occupation of a new housing project, a historic producer of conflicts (because of the arrival of new 
residents from outside the "community", because of the new conditions of conviviality in a condominium of buildings, because of the lack of services and shops in the surroundings) was not being accompanied by local agents. Although the right to housing is a historic and fundamental demand of mobilizations in the favela (cf., among others, Cunha 2016), all of our interlocutors said (and displayed through their actions) that they wanted to keep far from this process and the conflicts that it created. The only one who sought to call attention to the issue was a young resident, an artist who participates in a project to train cultural entrepreneurs. We also noted the same lack of involvement by community leaders when, a few months earlier, shacks were removed that had occupied the two poorest regions of the Cidade de Deus (the local city government justified the removals using the "technical" argument that the houses presented environmental risks). To understand this lack of participation we decided to return to our field notes.

On the other hand, we perceived that some of the arguments used to interpret the current weakness of the struggles in the "favelas" began to circulate between the university and the local agents. ${ }^{6}$ We refer in particular to the argument according to which the arrival of the Police Pacification Unit (and of the agents involved in the Social Police Pacification program, in their different formulations ${ }^{7}$ ), had provoked a weakening of the local associations, because these new actors presented themselves as "mediators" between the community and the outside agents, thus substituting the local agents (cf. Araujo Silva \& Carvalho 2015). Diversely, our observations in the field led us to suppose that to understand the current political dynamics in the "favela" it is necessary to situate the issue in a longer time frame, prior to the arrival of the Police Pacification Units.

In this article, we propose to assume the perspective of studies that in the field of anthropology of politics (Comerford and Bezerra 2013), strive to understand the dynamics of the relations between the agents assuming the polyphony of perspectives as the starting point and denaturalizing the idea of state as a univocal and rational institution. From this perspective, the understanding is that the agents are continually negotiating the positions that they assume in their practices and the moral categories that they use to take a distance from or approximate to one another, to form alliances or break them up, to weave personal relations and assume commitments. Thus, for example, if on one hand the definition of a frontier between people on the inside and outside (categories that are central to the discourse of our interlocutors) is continually reaffirmed, on the other hand we observe that these positions are not fixed and do not depend on objective data (such as being a resident or not of the location). They are relations, at the same time personal and political, that determine inclusion (or exclusion) in a determined category. In the same way, we are not interested in delimiting a specific segment, denominated by our interlocutors as "traffic", that is, the world of crime, or defining its characteristics and modes of operation. Instead of this, we are interested in understanding how the category "to be linked to trafficking" is triggered as an accusatory category, and its influence on the construction of alliances and conflicts.

Finally, we would like to make an important reservation in this introduction: our observations and our field work concern a specific place. We are convinced that today, as in the past - and even more so - there is an enormous heterogeneity among territories ordinarily called "favelas". Their political dynamics are very distinct, and depend on their location, process of occupation and urbanization, and on the presence of

6 About this circulation, which at times implies the "nativization" of analytical terms and concepts, see the Olivia Cunha discussion of black movements and the "politics of identity" (Cunha 2000).

7 The Social UPP program, administered by the state Secretariat of Social Assistance and Human Rights from 2010 until 2011 , came to be the responsibility of the city government and based at its Instituto Pereira Passos (IPP) in 2011. In the same year, the state secretariat implemented the Territories of Peace program whose agents acted in the favelas in a manner very similar to that of the local administrators of the Social UPP. After a few years, the Territories of Peace program was terminated, while in 2014 the Social UPP came to be called Rio + Social (Rio more social). 
various agents. It is not an easy task, and it is not our intention to produce generalizations. We simply hope that our observations contribute to the debate (among researchers and above all with our interlocutors in the field) about the processes underway.

The text is divided into three parts. In the first, after reviewing the main steps of the history of local struggles and the process that resulted in the organization of the Community Committee as an instance of local political articulation, we focus the engagement of this Committee on the management of the construction of a new housing project, which resulted from its political action. In the second part we present new local agents and articulations that became organized after the installation of the UPP. We conclude with some considerations about the recent transformations in the political processes in the Cidade de Deus.

\section{Actors and political processes in the "favela"}

On the walls of a local NGO, we found photos that portray images of a past that is significant to the history of the local struggles: the moment of strong mobilization at the time of the redemocratization of the country. It was a time in which "new personalities" entered the scene (Sader 1988): Catholic Churchrelated ecclesiastic base organizations, clubs of mothers, ${ }^{8}$ unions, resident associations. In one black and white photo, women in a march hold a banner on which it is written "10 years of May 1, 20 years of Cidade de Deus". The leaders of the NGO explained: for a long time the May Day commemorations were so significant in the community that for the residents the date came to symbolically represent the day of occupation of the Cidade de Deus. Another interlocutor from those years, a long time president of the residents association reported: "in the 199os, we held enormous assemblies with lots of people." The action of the local Catholic Church stood out, led by a priest who is still well remembered for his strong political and social action. The issue at the time was - in this "favela" formed from a housing project that took in residents removed from other "favelas" of the city (cf. Valladares 1978) - access to basic services, or that is "access to the city" (Machado da Silva 2002: 224). "This is the moment in which the identity of the "favelado" [favela resident] was formed. The central reference of this self image was neither poverty in general, or work or insertion in a productive process, but first the condition of housing" (idem, p. 228). The resident associations were, in those years, not only legally the main interlocutors with government; their directors were considered to be representatives of the residents (Pandolfi \& Grynszpan 2002: 244).

As they were for most social movements in Brazil, in the Cidade de Deus the 199os were years of fragmentation and changes in forms of action. In these years, as many have noted, the emphasis shifted from making demands and pressuring for the enactment of rights, to participation (that is involvement) in the administration of services and social projects in partnership with public and private agencies.

In the 199os, the growing appeal to the participation of civil society in the management of poverty, by means of the reinvention of charity as philanthropy, which found support and expansion in the ideology of partnership and governance, has resulted in the shrinking of the public space of debate, by reducing the specifically political field of formulation, negotiation and reaching agreements over interests. (Machado da Silva \& Leite 2004: 74).

\footnotetext{
8 In the 1960 and 1970 s the Catholic Church in Brazil stimulated the creation of various forms of organization among the poor in cities and rural regions to struggle for improved living conditions. In those years of strong repression from the military government, these organizations had an important role in the struggle against the dictatorship. The Grassroots Ecclesiastic Communities were spread throughout the country and were important spaces for political education and the articulation of popular movements. The mothers clubs specifically joined groups of mothers at churches in the peripheries.
} 
The Non Governmental Organizations (NGOs), born as entities to support social movements, became autonomous actors that conducted projects (mainly in the realm of promotion and education for citizenship). They administered resources, occupied chairs in the so-called instances of participation (councils, conferences) as representatives of population segments. ${ }^{9}$ Some researchers speak in this regard of a process of "NGOization" of the social movements (Silva 2007). If in the "favelas" it was initially the resident associations that assumed the administration of social projects (specifically linked to urbanization), with the control that organized crime began to exercise over these entities (cf. Pandolfi and Grynszpan 2002) the local NGOs began to take in the community leaders and in a certain way, to compete with the associations to assume representation of the interests of residents.

It should be emphasized that the NGOs did not completely substitute that action of the resident associations; the latter continued to perform important functions: until today, "they operate like mini city halls" (Pandolfi and Grynszpan 2002: 246) or local registrar offices, in particular because they had power to issue property deeds, records of purchase and sale and proof of residence. Moreover, we observe that in the Cidade de Deus, which even though they lost a monopoly on representation of residents in relation to state agencies, the presidents of the associations have an important interlocution with the police from the Police Pacification Unit. Depending on with whom they need to negotiate (with which local powers) the police turn to one or another type of local association.

In any case, in the new situation, overcoming the fragmentation, or that is, the articulation between organizations that conduct projects in distinct realms (education, healthcare, attention to a specific age group of the population, the environment) to define collective agendas comes to be a challenge (and at times is even a demand or imposition of funding agencies and partners). For this reason forums and networks and committees were born. If these instances should, according to the intentions, strengthen each one of the entities (through their collective strength), the need to articulate interests (and agents who are often linked to distinct political forces and compete for resources and for legitimacy of representation of the interests of the "community") absorbs much of their energy. According to one of our interlocutors: "there are lots of meetings, that seem to never begin or end, with little objectivity, nothing is decided".

The creation (or stimulus to the creation) of these instances of articulation, to serve as instances of representation and interlocution with public agencies is a recurring practice of local governments.

In the government of Saturnino Braga [1985], Government-Community Councils were created. Each council - composed of resident associations and religious, commercial and philanthropic agencies - indicated the priorities for their respective field (Pandolfi and Grynszpan 2002: 249)

In the Cidade de Deus, this function of "indicating priorities" was assumed in recent years by the Community Committee, which brought together leaders of local NGOs and resident associations and developed, as mentioned, a Local Development Plan. The Plan, organized with the assistance of a professor at the Federal University at Rio de Janeiro, in 2004, is based on nine themes - work, employment and income; education; health; housing; social advance; the environment; sports; culture; and communication - based on which actions were to have been systematized as priorities for the territory in the five following years.

9 About this process, and the thorny debate about the legitimacy of the NGOs as instances of representation of interests cf. Teixeira 2003 . 


\subsection{The Committee, the Agency and a new housing project}

It all began with the film. This is how the statements of our interlocutors generally begin when they want to tell visitors from the outside their stories about recent struggles and organizing. The international promotion and success of the film by Fernando Meirelles, "Cidade de Deus" (2002), caused indignation among residents of the location. The film portrays the "favela" strongly armed bandits (youth and children) live at war. With the film's success, the location known as Cidade de Deus became stigmatized throughout the world as a paradigmatic location of violence, where even children are involved with crime, are armed and kill.

Thus, our interlocutors say that after the promotion of the film the local articulations encountered a new energy. Some members of the local NGOs, leaders who were active in struggles in previous years, learned that a group of people (from the "community" - members of resident associations and NGOs with a community base - and from the outside - technicians from government, representatives of the nationally dominant Rede Globo television network, the United Nation's Children's Fund (UNICEF) and the so-called Forum Empresarial do Rio[Rio Business Forum] ]1 ${ }^{11}$ were meeting with representatives of the then National Secretary of Public Safety to jointly consider a type of action that could change the negative image presented by this film. The initiative had been motivated by a polemic generated by declarations made by rapper MvBill (a resident of the Cidade de Deus and who was responsible for the creation in 1999 of the NGO called the Single Center of the Favelas - CUFA). MvBill publically accused Paulo Lins - the author of the book "Cidade de Deus" (on which the film was inspired) and the realizers of the film - of "glamourizing" the violence without benefiting the "favela". ${ }^{12}$ The leaders of the local organizations sought access to the location of the meetings and the office of the resident association for the central region of the Cidade de Deus, but were not allowed to enter. In addition to wanting to participate in the articulation, in the opinion of our interlocutors, they needed to warn the authorities about the fact that people linked to "traffic" ${ }^{13}$ were participating in the meetings. They thus turned to their political allies in Brasilia, to warn of the danger of the National Secretariat of Public Safety making an alliance with these people. Afterwards, they were finally able to participate in the discussions that, in their opinion, took a new direction.

In this movement a first conflict was produced that caused a rupture with the rapper MVBill and Rede Globo. The broadcaster wanted to implant in the location a center for the project Criança Esperança [Child of Hope]. ${ }^{14}$ The local leaders then conducted a mapping of the existing associations that worked with children, arguing that, instead of constructing a new institution, Criança Esperança should donate money to strengthen organizations that are already active in the "favela". ${ }^{15}$ But Rede Globo did not accept the proposal (and the center of the Child of Hope project was built in another "favela" of the city). The space of dialog was abandoned, and the rapper also abandoned his efforts to work with the other associations.

\footnotetext{
10 The Cidade de Deus is treated by government at times as a "favela" and at times as a "formal" neighborhood of the city. This is because it is in fact a group of housing projects built at different times, to which new constructions characteristic of "favelas" were aggregated over time. The residents have property deeds and access to basic services of sanitation and electricity. But most of the residents refer to the location as a "favela" (Tommasi e Velazco, to be published).

11 Formed by business entities such as FECOMÉRCIO- RJ, SESC Rio, FENASEG, FETRANSPOR, SEBRAE-RJ and LAMSA.

12 Cf.: www.epipoca.com.br/noticias/ver/965o/polemica-o-rapper-mv-bill-diz-que-cidade-de-deus-o-filme-apenas-fez-gracinhas-sociais; http://cliquemusic. uol.com.br/materias/ver/mv-bill-e-a-polemica-com--i-cidade-de-deus--i- (last accessed on 21/01/2017).

13 In Rio de Janeiro the word "traffic" is used to refer to both the act and the actors and is used in this way in this article.

14 Criança Esperança [Child of Hope] is the name of a large campaign to encourage donations that is organized each year by the powerful television network Rede Globo to finance social projects to benefit children and adolescents.

15 The idea of creating new entities is common among the philanthropic institutions that frequently act in the territories without knowing the local reality and their web of associations; following the diagnoses of these institutions, in these territories there is a vacuum of services and "opportunities" that they must fill. Thus, these institutions construct and give publicity to narratives that emphasize their virtues.
} 
The meetings continued to take place, and thematic work groups were organized. The idea arose to create a Community Committee that would organize a more stable relations among existing organizations, NGOs and resident associations. Later, thanks to assistance from a technician from an NGO from the city, they decided to create a Local Development Agency, to give a legal status to the Committee and which would allow them to generate financing. "We did not know that what we were doing was Local Development", commented one of our interlocutors to justify the name of the new entity. In those years, the paradigm of Local Development (cf. Bocayuva, Silveira \& Zapata 2001; Martins, Vaz \& Caldas 2010) guided many actions aimed at confronting social problems. To create the Agency, they developed a project that was financed by a public company and administered by an NGO from the city. The dispute with the technician from the NGO responsible for administering the resources is another central episode in the narratives, and produced considerable distrust towards entities and people "from the outside", who in the opinion of some, were profiting from the work conducted by local agents. It also produced internal disputes among these agents, who had different opinions about the work conducted by the NGO.

Based on contact with some politicians, the Committee was invited to participate in a meeting with the government bank called the Caixa Econômica Federal, which provided funding for the construction of low income housing. The proposal was accepted, seeking the construction of a housing project in an area of the Cidade de Des considered extremely degraded, the Jardim do Amanhã, a swampy site, which belonged to the city and was occupied by "shacks" that housed some 628 families. This area was marked by its condition at the margin of the Cidade de Deus: until today the entire region is not found on the city government's maps, it is not included in the census and drug trafficking is ostensive.

According to the agreement, the federal bank (the Caixa) would finance the construction of homes while the city government would sell the land at a "symbolic price", but it would designate the builder responsible for the work. From the time of the negotiation with the Caixa, in early 2004, two years passed until the land was obtained from the city. The work was begun in 2006 and the project was delivered in 2008. The construction management was the responsibility of the community, that is, the leaders organized in the Committee. To generate the resources destined to managing the project, the Committee accelerated (and for some complicated) the process of creation of the Local Development Agency.

These types of "partnerships" according to Burgos, are not a novelty:

In various locations, state companies sign agreements with resident associations: while the former provide the projects and technical assistance, the associations receive the funds for hiring labor and keep an administrative fee of $5 \%$ which should be used for work that benefits the community (Burgos 1998: 43).

The group that administered the project was composed of one representative from the Caixa Econômica bank, members of local organizations and from an NGO based in the city. Nevertheless, there was one complication: the location of occupation is controlled by drug traffickers. Even the census of the existing houses and shacks and their residents was conducted some time ago by the mother of the top dealer in the region. It was impossible to not turn to her to conduct the registration of the residents who should occupy the new housing project. The relationship with this woman is until today a cause for significant disputes among the local leaders. More broadly, the dispute revolves around the question: how to handle relations with "traffic"?

According to the person responsible for the work from the Caixa Econômica bank, who is a regular visitor of the favelas of the city and knows them well, it would not be possible to conduct any project in the communities without negotiating with the dealers. "Anyone who says they do not do this is lying to you", he warns. But this opinion is not unanimous among the leaders. The limits and the forms of this negotiation are motives that trigger accusations, mistrust and breaking of alliances. 
The choice of members that were part of the remunerated technical group responsible for administering the project is emblematic of this type of conflict. For some, particularly those "from outside", the mother of the drug dealer should be part of the group; others disagreed. Another critical issue was the choice of a young social assistant who was "born and raised in the Cidade de Deus", to be part of the technical team that would conduct the registration. The woman, the daughter of an important drug dealer in the 1990s, was well known in the region, which, from one perspective, could facilitate negotiations. She told of an episode when, with a team of volunteer social service students, she conducted a survey of the residents. Shacks that were empty at the time were marked. Later, she received complaints that they belonged to dealers who were not home at the time. From her perspective, it was fair to register and grant homes to these people as well, which in fact took place.

Of all the accusatory categories used in relations among the residents of the "favelas" involved with politics, that of being complicit with "traffic" is certainly the most devastating. It symbolizes a dividing line between someone who is a "worker" and someone who is a "bandit", between someone who defends the state of law and those who use illegal practices. This is especially true in relation to handling resources, as in the case of the technicians responsible for the management of the construction project and the distribution of the houses.

It was precisely this need to have an entity where the money could circulate without fear of falling into the hands of people allied to "trafficking" that motivated the creation of the Agency. While the Committee is an open space, everyone could participate, the Agency is a more restricted space, whose members should be approved by a committee.

The new housing project was finally constructed, but combined with problems with the land and with the builder that was named by the city government the funds earmarked were not enough. The houses finally built were small and looked like railroad cars. "So finally they delivered the house, actually it wasn't a house. I think that the house is smaller than my room in my original house. I think that it was about $24 \mathrm{~m}^{2 "}$, said one of our interlocutors, one of the people responsible for the agency at the time of this process. Finally the responsibility for many of the problems of the project fell on their shoulders: "We were the ones who had to say to the residents that the $44 \mathrm{~m}$ had been reduced to $24 \mathrm{~m}^{2 "}$. That is certainly a high price to pay for the leaders (and a political gain for their partners in the state who were not blamed for the smaller size).

Despite this, the leaders were proud that they distributed the houses in a just manner. Except for a few who participated in the negotiations with the "traffic", the enormous majority - more than 600 were distributed with priority given to mothers who were heads of households; all the residents received property deeds when they received their keys.

Squalid shacks were substituted by small homes. But symbolic borders continued to haunt the region. Until today, it is a location without services, with lots of garbage scattered about, where not even the police from the Police Pacification Unit enter (because, according to the commander, it is a place of "bandits"). It is a place that is invisible to those who circulate through the central region of the community and can be impacted by the changes that took place after the installation of the Pacification Unit (paving, more commerce, better stores). At night, when entering the location, the impression is that one is crossing a border controlled by those who control the territory.

Moreover, the distrust and conflicts that participation in management of the project generated weakened the relations among the local organizations. Those who led the agency at the time of its creation, people with political and pedagogical training constructed in the decades prior to the struggles and investments in this training, left the leadership of the entity. The person who assumed did not have the same political strength in the "community". And was even linked to another political party. 
In fact, since we began to circulate through the Cidade de Deus, the Committee has met only intermittently and even, increasingly rarely. The Committee and the Agency were created with the intention of legitimizing the local organizations as special interlocutors in the actions of outside agents. This privileged interlocution, broadly demanded by the entities that participated in the Committee, was not recognized in the same way by all the possible interlocutors. The political and party alliances had a weight in this recognition, as well as ties of personal trust. Thus, the person who was for a few years at the head of the Secretariat of Work and Social Assistance of the city, a person close to the group of leaders connected to the Workers Party, established relations of trust with the members of the Agency. In this way, the Agency was able to be quite successful in its demands by administering some projects financed and sponsored by the city government, whose objectives were in keeping with the Local Development paradigm, such as the Programa Rio Ecosol ${ }^{16}$ and the Banco Comunitário. ${ }^{17}$ But other outside agencies selected other interlocutors from Cidade de Deus. The private companies, for example, turned to the commanders of the Police Pacification Units and administrators of the Social Police Pacification program and often did not even interact with the Agency.

Perhaps we can say that the arrival of the Police Pacification Units and of the administrators of the Social Pacification Units provoked a multiplication of ports of entrance to the location, for those who wanted to conduct some type of activity. No local institution has a monopoly on mediation with the community. And no outside entity can enter without the necessary mediation of some resident; for this reason, young people especially are frequently hired to serve as "local articulators", or to provide assistance to researchers, administrators or businesses.

Despite the regularly renewed rhetoric about the legitimacy of the "born and raised' in relation to agents from outside, we note that it is often the latter who provoke the activation of local agents. The Forums organized by the Social Police Pacification Unit program (cf. Rocha 2014 ; Gentil 2013), held monthly for a few months soon after the installation of the program in 2011, were important for reaffirming the political strength of the leaders connected to the Committee in relation to government authorities and outside agents. This included giving voices to historic demands, such as the construction of a high school or the implantation of a family health program. The conflicts that took place in these spaces, when the local actors presented their criticisms of the weak response of public administrators to their demands, show how much the acclaimed "active listening" (the declared objective of the Social UPP program) was not useful if the program was not able to mobilize the competent government agencies (leading to a "synergy" among government entities that the idealizer of the program emphasized as its purpose). This in fact provoked a crisis and the forums stopped being held.

With few exceptions, local managers of the program were important interlocutors for the leaders of the local NGOs. We can even say that a symbiotic relationship was created among them, some legitimating and making viable the actions of others. Thus the leaders could assume the role of representatives of the "community" and the administrators were able to conduct their many tasks (collecting information or making viable the collection of garbage, the organization of an event, the entrance of a partner to a business sector or the mapping of some type of activity).

16 Rio EcoSol is a project realized in the context of the national Public Safety with Citizenship program (PRONASCI) and administered by the Special Secretariat of Economic Development (SEDES) in the city of Rio de Janeiro. The project's objective is to support existing solidarity enterprises in four territories of Rio de Janeiro - Santa Marta, Cidade de Deus, Complexo do Alemão and Manguinhos - and to support and train new solidarity entrepreneurs in these locations. (cf.: http://rioecosol.blogspot.com.br/ last accessed on 16/og/2015). About the project, cf. Costa \& Castilho 2011.

17 The creation of the Bancos Comunitários in the favelas of Rio de Janeiro is another project administered by SEDES and realized from 2011 to 2015 . About the operations of the Bancos Comunitários cf. França Filho et al. 2012. 
As a consequence, the political weakening of the social Police Pacification program, with the departure of its mentor and general coordinator, also led to the weakening of the Committee and the Agency as representative bodies. But the orientation to stimulate partnerships with the private sector continued to be emphasized and was even strengthened by the new administrator of the program. In fact, as we have shown, the "pacification" led to the entrance in the "community" of various projects coordinated by the private sector aimed generally at increasing so called "entrepreneurship" among the residents. We will comment on some of these initiatives below.

\section{New forms of local associations}

\subsection{The Polo Inova [Innovation Pole]: promoting the "community" by increasing local commerce}

The Brazilian Support Service for Micro and Small Companies (SEBRAE) had entered the Cidade de Deus even before the Police Pacification Unit was established to stimulate formalization of businesses. The specific goal was to provide access to a federal program to promote legalization of businesses by granting tax benefits to so-called Individaul Micro Entrepreneurs (MEI) (cf. Freire 2015). In a small room at the facilities of the Center of Reference for Youth, a state government agency that serves as an open space for various activities, a SEBRAE consultant offered consulting twice a week and promoted educational courses for shop owners and local business owners.

But it was with the proposal to create a commercial center that SEBRAE's activities in the "community" became more significant. The first time that we participated in meetings that the consultant offered each week with local store owners we were surprised by the group dynamic: there were a large number of participants gathered on a Wednesday night, with mediation, supervision and energetic stimulus from the SEBRAE consultant. The meetings were always very lively and informal. Here, the division between the "born and raised" and those from the outside was much less clear. The group began conducting a mapping of commerce in the community. The declared objective was to undertake actions to support, strengthen and improve the quality of local commerce and resist the possible arrival of affiliates of large department stores that, attracted to the new consumer market known as "the new class C" (cf. Pochmann 2012), have entered many "communities" after a "pacification". The competitive prices of these large stores could threaten local shops.

The creation of the Innovation Pole in the Cidade de Deus was part of a new strategy by SEBRAE to support business in the "favelas". The program, initially called "SEBRAE in the communities", called for educational activities (about opening, maintaining and expanding one's own business) and the facilitation of access to credit, as well as support for the formalization of businesses..$^{18}$ The program was in keeping with the proposals of Peruvian economist Hernano de Soto, (whose book the "Mystery of Capital", is mentioned by our interlocutors from SEBRAE as their "bible"). This book argues for the need to transform what he calls "defective assets" into liquid capital, through the formalization of businesses, thus unleashing new frontiers for the accumulation of capital. De Soto presents Third World favelas as an "economy populated by heroic entrepreneurs" a popular uprising against state bureaucracy, a revolution from below (Soto, 2001).

18 It is interesting to note that SEBRAE maintained a program that seemed to be aimed at stimulating entrepreneurship among another population segment apparently "on the rise", the black population (cf. Silva 2016). 
SEBRAE, a public-private institution that provides financing that comes from the Guaranteed Fund for Time of Service (FGTS) - created with deductions from workers' pay, operates in close partnership with the state and municipal governments. Before the installation of the Police Pacification Units, SEBRAE in Rio de Janeiro operated in only one "favela" of the city (Rocinha) in a more systematic manner, and conducted isolated activities in others. It was with the arrival of the Police Pacification Units that the institution increased its operations in these territories. In addition to opening offices, it offered training courses, had a micro-credit program, and financed some isolated actions to strengthen and give visibility to some specific sectors, such as "street gastronomy" and tourist lodging in the "favelas".

The Cidade de Deus Innovation Pole was the first Pole ${ }^{19}$ created in a "favela". For this reason its members were frequently asked to demonstrate the success of this so-called "best practice" in activities promoted by SEBRAE and its government partners, like those during the large annual National Entrepreneurial Fair.

Of the group of merchants engaged in the creation of the Pole, one person actively participated who was also a member of the Agency and of the Community Committee. Inspired by the results attained by the organization of the merchants, he sought to approximate the two associations, particularly after the success of Inova Fashion, a fashion show that gave public visibility to the Pole. His idea was to have the Pole participate in the group of administrative entities of the Agency. But his efforts met criticisms that members of the Agency made of the merchants (who the Agency members say "only want profit"), criticisms that became frank distrust after the latter forgot to place the logo for the Agency on the banner of Inova Fashion, as one of the partners in the event organization. In fact, at that time, the Community Bank (managed by the Agency) had a stand to have its currency circulate among the other sales stands at the event.

Another successful action of the Pole was the creation of a booklet of discount coupons: each slip allowed the buyer a discount at one of the stores of the merchants that participated in the Pole in the Cidade de Deus, and in this way, stimulated local consumption.

While the members of the Agency criticized the activities of the Pole, members of the Pole sought to approximate to the Agency and the other initiatives existing in the "community". The merchants in the Pole embraced early on the idea of a social currency, with which the Community Bank administered by the Agency operated, recognizing its potential to stimulate sales of local products. They were also concerned about leveraging "community development". In their vision, the entire "community" would benefit with the success of local commerce. The possible visibility attained by the activities of the Pole could help the "community" free itself from the stigma as a violent territory (which was, to recall, the reason for the organization of the Committee after the realization of the film). Moreover, when I accompanied them on a visit in 2015 to the second edition of the National Entrepreneurial Fair, I noted that the merchants were particularly interested in visiting the stand dedicated to social work, and wanted to learn something about how to conduct actions of "social responsibility" in the community.

On the other hand, their actions sought to value a certain aesthetic, at the same time linked to the Afro theme and so-called "favela style", as they emphasized in the press release for Inova Fashion:

19 Through decree n. 31473 of 7 December 2009, the municipal government established the Polos do Rio (Poles of Rio) program that sought "the conjugation of efforts among municipal government and the private sector to recuperate economic activity and revitalize public spaces in areas with a concentration of companies, potential for economic development and local vocations". The program was coordinated by the Special Secretariat of Economic Solidary Development - SEDES. 
An event open to the public that would create many opportunities, leverage the neighborhood economy and give value to the fashion and aesthetics segment in the region. The main objective of Inova Fashion is to democratize fashion with a strong social appeal. The theme chosen was "Style Cidade de Deus-África" which sought to show the public that Cidade de Deus has its own style. (http:/|www.rio.rj.gov.br/web/guest/ exibeconteudo?id=4868974 accessed on 14/09/2015.)

That is, it sought to contribute to the positive valorization of the "favela" territories undertaken in various forms by government (as part of an attempt to renovate the vigor of the idea of the "Rio Cidade Maravilha", created for the realization of the World Cup and the Olympics in the city) and local associations.

The members of the Pole met at least once a week for three years. When there were training courses, they never substituted a meeting, which were collective moments (but led by a SEBRAE technician). These meetings did not include any "analysis of the conjuncture" (an activity quite common among NGOs) but planned, organized and evaluated activities. The goal of "making it happen" mobilized and motivated the encounters and the permanent education of the group and each person gave them considerable importance.

\subsection{Youth cultural producers}

In recent years, it has been common to encounter in large Brazilian cities a new social figure: the cultural entrepreneur. These are young people, generally participants or former participants in social projects, who are engaged in activities of production in the realm of culture and the arts: they are organizers of cultural gatherings, film producers, people who agency tourist and economic operations in the field of the arts and producers of artistic and cultural events. After "pacification" of the "favelas" many projects sought to increase the presence of these youth cultural entrepreneurs, through training courses and with small financing (generally in the form of "prizes"), and to give visibility to their activities, such as the realization of mappings ${ }^{20}$ and the organization of events and festivals like those organized by the "Creative Favela Circuit" promoted by the Creative Favela Program of the state Secretariat of Culture. Some (few and precarious) calls for projects offered financing to the activities organized by these youth, such as the Call for Projects for the Creative Favela Microprojects (http:/|www.favelacriativa.rj.gov.br/noticias/ edital-de-microprojetos-favela-criativa-2/). The financing was always very low and isolated (some R $\$ 10.000$ per project), but nourished a circuit of activism and militancy in the field of culture (Tommasi 2016).

The investments in culture realized as part of the projects to accompany the mega events also fed small specific calls for projects, such as the Local Actions project, which depended on "leftovers" from financing conducted in conjunction with the "Rio 450 years" celebration of the city's founding. During the organization of the Olympics, there was a significant investment of $\mathrm{R} \$ 17,7$ million in cultural activities, a quite limited portion of which was destined to finance so-called "local actions".

In addition to the public sector projects, there were also private sector investments (in particular from Rede Globo) to promote cultural agents in the favelas. These included funds for: "partners of RJ", dancers for the program 'Esquenta!', consultants from the popular Sunday variety show Faustão, co-directors of

20 One example of this is the project Solos Culturais [Cultural Solos. "Solo" in Portuguese refers to both a "solo" or individual performance and "soil" as in ground for planting], which conducted a mapping of cultural initiatives realized by young people in five favelas in the city and promoted their formation. The name of the project refers to the idea of the fertility and creativity of the favela, as well as the individual aspect of creativity within a collectivity. (cf: http://www.solosculturais.org.br/o-que-e/). 
films ${ }^{21}$ (such as the film " $5 \mathrm{xfavela:} \mathrm{agora} \mathrm{por} \mathrm{nós} \mathrm{mesmos"} \mathrm{[} 5 \mathrm{x}$ favela: this time by us]). The opportunities to work are few, yet feed the dreams of many people.

Many youth who act as cultural producers have completed projects conducted by non governmental organizations that, since the 199os, proposed to offer these young people, as alternatives to involvement in "traffic", educational courses (or better training courses) in the realm of a non-specified field of "art and culture": video, dance, music, graffiti or theater. If culture, as noted by Manuel Delgado, assumes "salvational" functions (Delgado 2008: 6), these can be offered for the "salvation" of the problem subjects who embody, in the social imagination, the fear of violence: the young black residents of the favelas. They include a varied group of projects, agents and practices that conform to what I call the mechanism of art and culture. They substitute the traditional professionalization courses to occupy the supposedly leisure time of these youths and dispute them with "traffic", so that they become workers and not bandits (cf. Tommasi 2014a).

In the Cidade de Deus, the activism of young producers and cultural agitators also increased. The old local leaders, in general, did not look with condescension on these youths, for whom work, political activism, leisure, art, and fun are decidedly combined. The traditional local leaders referred to these youth with accusatory categories such as cooptation, individualism, interest in profit and said that "they just want to appear". The youths in turn had no less explicit criticisms of the former leaders of the Committee, who in the youth's opinion, "just know how to talk". This was made clear when we questioned one of our young interlocutors about the Committee meetings:

There was lots of fighting, lots of petty politics...we say petty because politics should be something good, when its not good, its petty.

There is, therefore, an evident generational distance. The youth, mobilized by the idea of "making things happen", tired of not being heard by those who in their opinion "call themselves the 'voice of the Cidade de Deus'", find in the precarious incentives to cultural initiatives an opportunity to be engaged and "get by" at the same time, that is, to earn the money needed to survive. Another youth explained this in his statement about the employment opportunities that the young favela residents usually have:

As soon as we are born we are taught to believe that what is possible is impossible, while in other places of the city people grow up with the idea that life is an ocean of opportunities. Its never easy, but its possible. But not here, 'it's difficult, it's impossible, and oh, there's a job at McDonald's'. So I think that this is the difference for the producer from the favela, to be able to believe that it is possible.

For many of these young people culture became an alternative to the routine and poorly paid work. As we noted (Tommasi 2016) the activism in the field of culture cannot simply be labeled as alienation. Our young interlocutors in Cidade de Deus clearly believe that the places reserved for them are subaltern ones, even in the field of art and culture.

They want to say that the "favelado" sambas well, dances well, sings well...Brother, that's what's left! There's no way, that's what's left for us ...and we're going to do poorly? That's what's left, culture and art, which is a bit abstract...But no one says they do well in something more precise: 'blacks are good at mathematics' 'blacks are good at medicine', man, what we need now is to create the opportunity so that he can do well in other things too.

21 "Parceiros do RJ" [Partners of Rio de Janeiro] was a news program on RJTV, broadcast at mid day by the Rede Globo. On it, youths presented their "communities", highlighting "positive points" (to contrast with the daily news of violence and criminality in the favelas) such as people and cultural manifestations. The program Esquenta! presented artists from the "favelas" and the peripheries of the country, as well as leaders of NGOs and other institutions found in these places. In this way it sought to be a channel of access for the "new class C" [a new lower middle class] to the consecrated programing of the powerful Rede Globo. 
Another one of our interlocutors explained that there is a label that should be fought: "the producers from the favela are always thrown into the realm of the NGOs, and the need to do something social. For me this labeling shouldn't exist, because you diminish the person's work".

There are some youth, as we mentioned above, who do not avoid denouncing the irregularities, the lack of transparency, the conflicts over the assignment of apartments in the new housing project of the Minha Casa Minha Vida; that is, those who embrace the cause of the housing issue (and not only cultural activism).

Finally, it should be mentioned that the activities of these youth are quite fragmented. Some join together in groups, which at times last for the time of a joint project. But concerns about organization are always present, even if the modalities of the financing, through public calls for projects and awards, make the youths competitors for extremely limited resources.

\section{Some considerations about conflicts, representation and alterity: recent transformations in political processes in the Cidade de Deus}

We hope that our observations have made clear that what characterizes the territories considered to be at the margins of the city is not a "lack" of (as was proposed for a long time by the sociological literature) but a multiplicity of agencyings and interventions of various agents who are interested in governing the poor (Procacci 1993). In this dense and complex context, how do the residents organize and act politically? And how can we characterize the transformations that have occurred in recent years in the attempts to organization local associations?

A first question concerns the nature of the conflict. For Machado da Silva, the conflicts addressed by the associations that were created in the favelas in previous decades were related to the issue of land ownership: access to housing, urban infrastructure and facilities, access to the city. In recent years, the activities of both the Agency (the program Rio Ecosol and the Community Bank) as well as that of Innovation Pole, in the Cidade de Deus, are aimed at what they define as economic development of the territory. Development is a polysemic term that adapts to multiple interpretations. The analysis of the term goes beyond the purpose and limits of this article. In this case, the programs in question seek to promote access to wealth through promotion and increase of commercial and entrepreneurial activities and access to credit. In this sense, our first affirmation is that there is considerable continuity between the actions of the Innovation Pole and the Agency. In contrast, the questions related to urbanization (both the construction and occupation of new housing projects, as well as removal of housing) are currently not the object of demands. As we have mentioned, the last time that local leaders were involved in the administration of a housing project they entered a web of complex relations, which involved negotiating with different agents, even with the "traffic", and the internal conflicts that resulted from this significantly weakened the attempt at collective organization. In name of "partnership", the political agents from the state let fall on the shoulders of local leaders part of the responsibility for the management of the process (without, however, giving up control of important elements, such as the contracting of and negotiating with the builder responsible for the construction) the success of which was inevitably polemical.

Thus, like the people from the Agency, the members of the Innovation Pole are concerned with the economic development of the community and the improvement of living conditions of residents. For the former, political awareness and citizenship are recurring terms: for the latter, the grammar is different (to be an entrepreneur, socially responsible). But, all are concerned about doing something to contribute to change the image of the "favela", to promote the "community" on the outside and to improve the living conditions of the residents. For the members of the Committee, in the past, doing something involved being responsible for the management of a public project, the construction and assignment of low 
income housing. Today, it is to manage a local development project that was offered by public entities. If "negotiated management" (Machado da Silva 2002) has substituted the grammar of rights, the notion of development, especially if treated as a technical and not a political issue, has diluted the conflicts.

For the merchants in the Pole, who are much more pragmatic, to do something means to economically leverage their community, to offer their products in the market and to improve their quality, to increase their businesses and make them more economically profitable.

For the young cultural producers, whether they are organized or not in collectives, what is at stake is access to work. They demand access to a type of work that values their desires and abilities, which breaks with the fate traditionally reserved to the "favelados": to be cheap labor or enter the world of crime. They also demand access to public funds.

Another question to be raised concerns the role of the local organizations as representatives of the "community". While the leaders of the associations linked to the Agency present themselves in public forums as representatives of the "community", the merchants in the Innovation Pole never assume this function, and do not seek it. The young cultural producers do not specifically affirm they are representatives of the community. But on some occasions (above all at media events) they present themselves as actors whose speech is legitimated by their housing conditions, people who know what they are speaking about because they have lived it. In this way they insist on the legitimacy of their speech. The knowledge that they have of the territory, of the internal dynamics of the favela, is an important part of the social capital that they use to insert themselves in the labor market (as local agents of government or private sector projects, as reporters or as supporters of audiovisual productions that use the "favela" as a location).

If the leaders of the local NGOs took the place of the leaders of the resident associations as the "community" representatives, their legitimacy at the interior of the "favela" is now questioned, if we consider the low participation of residents in initiatives that they promote (not considering attendance in the courses they organize). The NGOs are limited to managing projects (mostly for training or education). Paradoxically, even if the triggering of identity (the argument of being "born and raised" in the "favela") is used to legitimate this speech and action, their political strength as representatives of the "community" is more significant outside than inside it. We can say that "community" is a category used to manifest alterity in relation to others (who may include, depending on the circumstances of the context in which speech is produced, residents of the "asphalt", ${ }^{22}$ promoters of projects, technicians from NGOs, the city, politicians, researchers) and not as an ontological category, which names a collective actor or even less so, an empiric fact. For this reason the positions and the affirmation of identity, must be continuously negotiated.

No one in the "favelas" today organizes events that have significant participation of residents. To the contrary, when there is a political event of public importance, the presence of people "from the outside" is much more significant. To mobilize the residents is a concern of all, but is only attained by artistic and recreational manifestations (funk dances, the gay parade of the Cidade de Deus, the traditional June festivals organized by the resident associations).

We agree, therefore, with Marcela Carvalho, when she argues about a "crisis of representativeness which is combined with a crisis of legitimacy" of the political organizations in the favelas (Araujo Silva 2013:3 ). But this crisis of legitimacy, in our understanding, is not due only to the formation of illegal markets and to the establishment of the logic of partnerships with public and private entities. This crisis is also a reflection of the strong socioeconomic heterogeneity of the residents, which does not allow someone to speak "in

22 In Rio de Janeiro, the term "asphalt" designates all the residential territories of the city that are not considered "favelas". The contrast between "favela" and "asphalt" has constantly fed the imaginary of the city, since its enunciation by the journalist Zuenir Ventura (1994). It is against this duality that, in this text, we affirm the complexity of relations between political agents in the city. 
name of". This heterogeneity is expressed in the distinct expectations about insertion in the labor market, distinct agendas concerning access to the city. If at the beginning of the urbanization of the "favelas" the residents needed to join together to build (and demand) minimally decent living conditions, today their agendas are different, they concern access to the market, as producers and consumers, to work (particularly in self-employment) and the problem of debt.

The possibility for articulation among the local organizations is undermined from within by the logic of financing via social projects and public bids for projects, which promote a "social competition" (Donzelot 2008) and competition between organizations (and between the youth groups or collectives) to access resources. Divisions are also produced by various alliances established with politicians, belonging to different parties or to different currents within them. There are different understandings and above all, distinct practices for relating with the agents "from the outside" but also with those from within (the "traffic" and in these times after the Police Pacification Unit, the police) which dispute control over the territory.

In this situation, the presence of "traffic" and the need to negotiate with it is one more reason to use accusatory categories, to produce ruptures. The political cost, the loss of legitimacy (and reputation) for being involved in this business is great. But, at the same time, as our interlocutors argue, it is not possible to intervene in the production of urban space, implement the right to housing or promote a supposed development without negotiating with those who control the territory (the "traffic", but also emissaries of politicians in power or the police). The presence of the Police Pacification Unit is another element that now complicates the field of disputes, because residents who act politically, linked to local NGOs, do not want to approach the commanders of the police forces who, despite the rhetoric about "proximity policing", have not changed their practices and their image of forces of repression, as violent actors. The police continue to kill in the "favelas" (cf. Justiça Global 2016).

On the other hand, even if the merchants move in the field of production of wealth, this does not mean that their activities do not involve conflicts. There are both redistributive conflicts (generating more wealth for the local merchants, impeding the entrance of large commercial businesses that asphyxiate local commerce) and conflicts over recognition (the "favela style" as a mark of an aesthetic, a current expression of a "political identity"). In turn, the conflicts expressed by the young cultural producers concern access to public resources, but also question the labor market and try to break the barriers that always relegate them to subaltern positions. They also dispute the symbolic production of the "favela".

In the "favela" - and on the "asphalt" - collective actors are now organized in a spirit of collaboration and not of repudiation of instituted policies, and with a recognition of the diversity of supposed identity minorities (blacks, women, favelados), and of the valorization of the enterprising capacity (or "resilience") of individuals. But, if the grammar is similar, the condition of subalternity of the favelados has not changed. The conflicts reappear in the clear words of our young interlocutors who demand access to a piece of the market. We can recall, for example, that although they were named as an example of a "good practice", the merchants of the Innovation Pole were not able to conquer a space of visibility at the Entrepreneurial Fair. Unlike street food entrepreneurs or promoters of tourism in the "favelas".

In the discourse of the members of the Innovation Pole there is not one explicit reference to the dichotomy between being "born and raised" in the "favela" or being from the outside. Many of them present themselves publically as being "born and raised" in the "favela", a condition that provides legitimacy, but in their discourses and in their practices there is a "gray zone" (Roy 2011). ${ }^{23}$ The majority of the stores are located in the central region of the Cidade de Deus, which since the so-called pacification

23 An example of a person who can be situated in a "gray zone" is the technician hired by SEBRAE to assist the Polo. She is black and a resident of a peripheral region of the city. She has worked as a consultant on socio-economic projects for some time. 
is the most valued and has lots of shops, or in the regions that border the "asphalt". Some of them live in condominiums close to the "favela". There is a great heterogeneity of living, social, economic, cultural and territorial conditions among them. We observe that they use a dichotomic category (from inside or from outside) when they need to legitimate themselves, marking a condition of alterity, not to disqualify or establish a distance. To the contrary, they are completely willing to dialog and collaborate with "outside" agents. They do not distrust the intentions of those who come to know, assist or provide education. But, they are willing to struggle for their rights, to make their voices heard in relation to the entity that sponsors their organization. They are able to have technicians from the entity whose work they do not like replaced and are aware that they are unfairly under valued by the institution. Through their products, they call for the valorization of an identity of the "favelado" (the "favela style", the "Afro aesthetic"): an economic but also political valorization.

Although leaders of the Agency distrust the merchants in the Innovation Pole ("I sell the community", one of the local leaders told us, "they sell themselves") the practices of the two groups are not very different: the two are related with entities "from the outside", that intend to conduct actions at the location in exchange for visibility and political gains. "Everyone comes here and does what they want", one of our young interlocutors told us. That is, they impose their projects, their vision about what is best for the "development" of the community. It seems that there is a great flux of projects, interventions, agents and resources. The projects produce worlds, markets, interests, relations and sociabilities that last for the time of the project and at times, disappear without leaving a trace.

\section{Translated by Jeffrey Hoff}

Received: January 24, 2017; Approved: May 26, 2017 


\section{References}

ARAUJO SILVA, Marcela Carvalho. 2013. "A transformação da política na favela um estudo de caso sobre os agentes comunitários". In: Anais do 370 Encontro Nacional da ANPOCS, Águas de Lindoia. Mimeo.

; CARVALHO, Monique Batista. 2015. "Circuitos políticos em uma favela pacificada: os desafios da mediação". Dilemas: Revista de Estudos de Conflito e Controle Social, 8(1): 03-70.

BOCAYUVA, Cunca; SILVEIRA Caio; ZAPATA, Tania. 2001. Ações integradas e desenvolvimento local: tendências, oportunidades e caminhos. São Paulo: Instituto Pólis.

BURGOS, Marcelo. 1998. "Dos parques proletários ao Favela-Bairro: as políticas públicas nas favelas do Rio de Janeiro". In: A. Zaluar e M. Alvito (orgs.), Um século de favela. Rio de Janeiro: Editora FGV. pp. 25-6o.

CANO, Ignacio (org.). 2014. Os donos do morro: uma avaliação exploratória do impacto das Unidades de Polícia pacificadora (UPPs) no rio de Janeiro. São Paulo: Fórum Brasileiro de Segurança Pública; Rio de Janeiro: LAV/UERJ.

CARDOSO, Lucio Adauto (org.). 2013. O programa Minha Casa Minha Vida e seus efeitos territoriais. Rio de Janeiro : Letra Capital.

COMERFORD, John ; BEZERRA, Marcos Otavio 2013. "Etnografias da política: uma apresentação da Coleção Antropologia da Política". Análise Social, 2(207): 465-489.

COSTA, Marcelo Henrique da; CASTILHO, Sérgio Ricardo Rodrigues. 2011. "Desenvolvimento econômico solidário e segurança pública na cidade do rio de janeiro: estratégias para a ação". Mercado de Trabalho, 46: 57-61. Brasília: IPEA.

CUNHA, Olivia. 2000. "Depois da festa. Movimentos negros e 'política de identidade' no Brasil". In: S. Alvarez, E. Dagnino, A. Escobar (orgs.), Cultura e política nos movimentos sociais latino-americanos. Belo Horizonte: UFMG. pp. 333-380.

CUNHA, Marize Bastos da. 2016. "Cenas históricas de participação popular na constituição de um campo de frontera nas favelas do Rio de Janeiro”. In: I. R. Rodrigues (org.), Vida social e política nas favelas: pesquisas de campo no Complexo do Alemão. Rio de Janeiro: IPEA. pp: 15-42.

DELGADO, Manoel. 2008. "La artistización de las políticas urbans. El lugar de La cultura em las dinâmicas de reapropriación capitalista de la ciudad”. Scripta Nova: Revista Electrónica de Geografía y Ciencias Sociales, 12(270). http://www.ub.es/geocrit/sn/sn-27o/sn-270-69.htm.

DE SOTO, Hernano. 2001. O mistério do capital. Rio de Janeiro: Record.

DONZELOT, Jacques. 2008. “Le social de compétition”. Esprit, 51-77.

FRANÇA FILHO, Genauto Carvalho de; SILVA JUNIOR, Jeová Torres and RIGO, Ariádne Scalfoni. 2012.

"Solidarity finance through community development banks as a strategy for reshaping local economies: lessons from Banco Palmas". Rev. Adm. (São Paulo) [online], 47(3): 500-515.

FREIRE, Carlos. 2015. "Os mercados populares do centro de São Paulo: dispositivos comerciais globalizados". In: A. Peralva; V. Telles (orgs.), Ilegalismos na globalização:migrações, trabalho, mercados. Rio de Janeiro: Editora UFRJ, 2015. pp. 287-303.

GENTIL, Vinicius Miranda. 2013. “Mangueira: o associativismo e a política em tempos de UPP”. Recôncavo: Revista de História da UNIABEU, 3(4): 179-202.

JUSTIÇA GLOBAL. 2016. "Informe sobre recentes violações de direitos humanos cometidas pelo Estado brasileiro contra a população das favelas e periferias da cidade do Rio de Janeiro/RJ”. www.global.org.br (último acesso 24/01/2017).

MACHADO DA SILVA, Luis Antonio. 2002. "A continuidade do 'problema da favela". In: L. Oliveira (org.), Cidade: história e desafios. Rio de Janeiro: Editora FGV/CNPq. pp.220-237. 
; LEITE, Marcia Pereira. 2004. "Favelas e democracia: temas e problemas da ação coletiva nas favelas cariocas". In: Machado da Silva et al. (orgs.), Rio: a democracia vista de baixo. Rio de Janeiro: Ibase. pp. 31-78.

MALAGUTI, Vera. 2011. "O Alemão é muito mais complexo". Texto apresentado no 17오 Seminário Internacional de Ciências Criminais. São Paulo, 23 julho. http://www.labes.fe.ufrj.br/arquivos/Alemao_complexo_ VeraMBatista.pdf. Mimeo

MARTINS, Rafael; VAZ, José Carlos e CALDAS, Eduardo. 2010. "A gestão do desenvolvimento local no Brasil: (des)articulação de atores, instrumentos e território". Revista de administração pública, v. 44, n. 3, pp.559590.

PANDOLFI, Dulce; GRYNSZPAN, Mario. 2002. "Poder público e favelas: uma relação delicada”. In: L. Oliveira (org.), Cidade: história e desafios. Rio de Janeiro: Editora FGV/CNPq. pp.220-237.

POCHMANN, Marcio. 2012. Nova classe média? O trabalho na base da pirâmide social brasileira. São Paulo: Boitempo.

PORTELLI, Alessandro. 1998. “O massacre de Civitella Val di Chiana (Toscana, 29 de junho de 1944)”. In: M.

M. Ferreira e J. Amado (orgs.), Uso e abusos da História Oral. Rio de Janeiro: FGV. pp. 103-13o.

PROCACCI, Giovanna. 1993. Gouverner la misère. La question social en France (1979-1848). Paris: Seuil.

ROCHA, Lia de Mattos. 2014. 'Da 'cidade integrada' ao 'empreendedorismo': participação e gestão nas margens em tempos de 'pacificação"'. Texto apresentado no $38^{\circ}$ Encontro Anual da ANPOCS. Caxambu. Mimeo.

ROY, Ananya. 2011. “Slumdog cities: rethinking subaltern urbanism”. International Journal of Urban and Regional Research, 35(2): 223-38.

SADER, Eder. 1988. Quando novos personagens entram em cena: experiências, falas e lutas dos trabalhadores da Grande São Paulo (1970-80). São Paulo: Paz e Terra.

SILVA, Ana Claudia Cruz da. 2007. "Novas subjetividades e 'onguização' nos movimentos negros de Ilhéus, Bahia”. Ilha, 9(1): 48-66.

SILVA, Gleicy Mailly da. 2016. Empreendimentos sociais, negócios culturais: uma etnografia das relações entre economia e política a partir da Feira Preta em São Paulo. Tese de Doutorado. São Paulo, USP.

TEIXEIRA, Ana Claudia. 2003. Identidades em construção: as organizações não governamentais no processo brasileiro de democratização. São Paulo: Annablume.

TOMMASI, Livia De. 2014a. "Juventude, projetos sociais, empreendedorismo e criatividade: dispositivos, artefatos e agentes para o governo da população jovem". Passagens: Revista Internacional de História Política e Cultura Jurídica, 6: 287 - 311. 2014b. "Naturellement créatifs': pacification, entreprenariat e créativité dans les favelas cariocas".

Bresil(s), 6: 55-74. . 2016. "Jovens produtores culturais de favela". Linhas Críticas, 22(47): 41-62.

TOMMASI, Livia De; VELAZCO, Dafne. 2013. "A produção de um novo regime discursivo sobre as favelas cariocas e as muitas faces do empreendedorismo de base comunitária”. Revista do Instituto de Estudos Brasileiros, o: 15-42. 2016. "O governo dos jovens e as favelas cariocas". Dilemas: Revista de Estudos de Conflito e Controle Social, 9: 531-556. . (to be published). "Politica e diritto all'abitazione in uma favela carioca". Cartografie Sociali.

VALLADARES, Lícia. 1978. Passa-se uma casa: análise do Programa de Remoção de Favelas do Rio de Janeiro. Rio de Janeiro: Zahar. . 2005. A invenção da favela: do mito da origem a favela.com. Rio de Janeiro: editora FGV. 
VELAZCO, Dafne. 2013. O discurso da "cidade integrada" e suas implicações no cotidiano de jovens moradores da Cidade de Deus. Monografia em Ciências Sociais. Niterói, UFF.

2017. A trama das casas: mulheres e cotidiano na Cidade de Deus. Dissertação de Mestrado em Ciências Sociais. Rio de Janeiro, PPCIS/UERJ.

VENTURA, Zuenir. 1994. A cidade partida. São Paulo: Companhia das Letras.

Livia De Tommasi

ABC Federal University, Post Graduate Program in Human and Social Sciences,

São Bernardo do Campo/SP, Brazil.

E-mail: livia.detommasi@gmail.com

Dafne Jazmin Velazco

State University of Rio da Janeiro, Post Graduate Program in Social Sciences, Rio de Janeiro/RJ, Brazil.

E-mail: dafnejav@gmail.com 